\title{
INVESTIGATION OF THE EFFECT OF ARTEMISIA L. HERB EXTRACTS ON THE PROGRESS OF THE TOXIC TETRACHLOROMETHANE LIVER DAMAGE
}

\begin{abstract}
Introduction. Artemisia L. genus species are the promising sources for the manufacturing of drugs with hepatoprotective activity. They are used as appetizing, anthelmintic, bactericidal, choleretic and anti-inflammatory remedies. The pharmacological activity of Artemisia L. species is caused by the presence of different groups of biologically active substances.

The aim of the study - to learn the acute toxicity and the effect of Artemisia absinthium and Artemisia vulgaris water-alcohol extracts on the progress of the toxic tetrachloromethane liver damage.

Research Methods. The method of preclinical study of drugs safety was used to determine the acute toxicity. The investigation of hepatoprotective activity of Artemisia absinthium and Artemisia vulgaris extracts was performed using the model of acute tetrachloromethane hepatitis. Hepatoprotector of local manufacturer ("Silibor" tablets) was used as the reference drug.

Results and Discussion. It was found that intragastric administration of Artemisia absinthium and Artemisia vulgaris extracts at the dose of $6000 \mathrm{mg} / \mathrm{kg}$ does not lead to the death of animals. There were no changes in the integral, hematological, biochemical parameters and in the morphological structure of the internal organs of experimental animals. It allows to characterize the extracts at this dose as almost non-toxic ones ( $V$ toxicity class, $L D_{50}>5000 \mathrm{mg} / \mathrm{kg}$ ) according to the toxicity classification of substances. The results of Artemisia absinthium and Artemisia vulgaris extracts study indicate that they show the distinct hepatoprotective activity in condition of acute toxic liver damage. They suppress peroxide destructive processes and reduce the evolution of cytolysis syndrome and their effects are no inferior rather than the effect of tablets "Silibor".

Conclusions. The study of acute toxicity of Artemisia absinthium and Artemisia vulgaris extracts after their intragastric administration at the dose of $6000 \mathrm{mg} / \mathrm{kg}$ does not lead to the animals death. They were tidy and had the good appetite. The animals reacted adequately to sound and light stimulation. The processes of urination and defecation were unchanged. Breathing disorders and seizures were not observed. The investigated Artemisia absinthium and Artemisia vulgaris extracts demonstrate hepatoprotective activity in condition of acute toxic liver damage. This is proved by decreasing in the intensity of lipid peroxidation and in the toxicity of tetrachloromethane. Biochemical parameters of the animals' blood and the liver homogenate became responded to the level of intact animals.
\end{abstract}

KEY WORDS: acute toxic liver damage caused by tetrachloromethane; extract; Artemisia absinthium; Artemisia vulgaris; histological examination.

INTRODUCTION. Artemisia genus species are promising sources for the manufacturing of drugs with hepatoprotective activity. They are used as appetizing, anthelmintic, bactericidal, choleretic and anti-inflammatory remedies. The pharmacological activity of Artemisia L. species is caused by the presence of different groups of biologically active substances [1].

Artemisia absinthium herbal medicines stimulate reflexively the function of glands of the gastrointestinal tract. They also enhance the bile excretion and significantly improve the digestion. Terpenoids of the plant show the pronounced anti-inflammato(c) R. A. Hrytsyk, O. A. Struk, V. M. Ivanochko, 2019. ry effect, stimulate the functions of the reticuloendothelial system and the phagocyte activity. In addition, Artemisia absinthium has anti-inflammatory, antiseptic, anthelmintic and anti-ulcer properties. Artemisia vulgaris herbal medicines have the calming effect, relieve cramp and convulsions, have the mild hypnotic and diaphoretic effects, stimulate the appetite and regulate the functional activity of the digestive tract $[1,2]$.

To determine the safety of new drugs or substances, it is mandatory to study their toxicity [3].

Diseases of the hepatobiliary system are an important problem of the modern medicine. Medical and social importance of liver toxicity is due to en- 
vironmental pollution, widespread use of chemical compounds in the everyday life, the alcohol abuse and complications of pharmacotherapy. All these factors affect on the liver - the central organ of metabolism and biotransformation and cause its damage [4-7]. Hepatoprotectors are prescribed to treat the liver disorders. They are capable to protect or even stabilize the membranes of hepatocytes. There are not a lot of modern hepatoprotective agents in the Ukrainian pharmaceutical market. Therefore, it is important to search for new medicines with hepatoprotective activity of synthetic and natural origins. Plants that contain polyphenolic substances and are capable to influence on the main links in the hepatobiliary system pathogenesis are of the greatest interest $[1,8]$.

This scientific research is a part of the complex research work of the Pharmacy Department of Ivano-Frankivsk National Medical University "Research of cultivated and wild medicinal plants of the Western region of Ukraine and development of technologies for their use with therapeutic purpose" (number of state registration 0118U003809).

Acute toxicity and hepatoprotective activity of Artemisia absinthium and Artemisia vulgaris extracts were investigated with the help of professor G. M. Ersteniuk (the head of Biological and Medical Chemistry Department named after academician G. O. Babenko, Ivano-Frankivsk National Medical University) and professor Y. S. Gudyvok (the professor of Pharmacology Department, Ivano-Frankivsk National Medical University).

The experiments were performed on the basis of the training-experimental complex "Vivarium" of Ivano-Frankivsk National Medical University. We used white non-linear mature male mice weighing 19-21 $\mathrm{g}$ and white male rats without breed weighing $180-250 \mathrm{~g}$. Animals were kept in the vivarium in accordance to the requirements of sanitary and hygienic standards and using the standard ration.

The aim of the study - to learn the acute toxicity and the effect of Artemisia absinthium and Artemisia vulgaris water-alcohol extracts on the progress of toxic tetrachloromethane liver damage.

RESEARCH METHODS. All practical material is processed by the method of variable statistics by the calculation of the arithmetic average mean and its standard error. The reliability of the compared values was evaluated by the Student's criterion. The probability level was accepted as $p \leq 0.05$ [9].

The study of acute toxicity of Artemisia absinthium and Artemisia vulgaris extracts was conducted using white non-linear mature male mice.

The animals were kept in standard sanitary conditions (at the temperature of $20-24^{\circ} \mathrm{C}$, humidi- ty of $50-55 \%$ and natural day-night light mode) in the plastic cages.

The method of preclinical study of drugs safety was used to determine acute toxicity [3]. The study was conducted in the reduced format using only one species of animal (white non-linear mature male mice) because of planning the complete preclinical study in future. Animals were divided into 3 groups of 6 animals. The maximum dose that depends on the route of administration is the limit indicator of acute toxicity [3]. The investigated extracts were administered intragastrically. The animals of group 1 were administered Artemisia absinthium extract at the dose of $6000 \mathrm{mg} / \mathrm{kg}$; the animals of group 2 were administered Artemisia vulgaris extract at the dose of $6000 \mathrm{mg} / \mathrm{kg}$; animals of group 3 were intact. The animals were monitored for 14 days.

The degree of extracts toxicity was evaluated based on their mortality and the changes in the general condition of the animals, dynamics of their body weight, hematological and some biochemical parameters of blood. The toxicity class was determined according to the common classification [3].

The work was carried out in accordance with international and national requirements for the humane treatment of animals and in compliance with the requirements of Directive 86/609/EEC about the protection of animals of the "European Convention for the Protection of Vertebrate Animals which are used for Experimental and Scientific Purposes" [10-13].

The study of biochemical parameters was carried out on the basis of the Center of Bioelementology of the Ivano-Frankivsk National Medical University (accreditation certificate number 037/14, April 29, 2014).

The effects of drugs on the hemogram were evaluated by the content of erythrocytes, leukocytes and hemoglobin in the peripheral blood of animals and were determined by the common methods. The determination of erythrocyte sedimentation rate (ESR) was performed by the Panchenkov method. Glucose oxidase method was used to determine the serum glucose concentration. Sets of reagents of Filisit-Diagnosis (Ukraine) were used to determine urea with the help of urease method. Hypobromite method was used for searching residual nitrogen (Rappoport-Eichhorn method), and the Ilk method was used to determine the total content of cholesterol. The state of the antioxidant system was evaluated in the activity of ceruloplasmin. It is synthesized in liver hepatocytes by combining the alpha-2 globulin fraction with 6 copper atoms and it is a protein enzyme. Ceruloplasmin is the main extracellular antioxidant that circulates in the blood and prevents the appearance of harmful underoxidized metabolism products (free radicals, bio- 
logically active amines, etc.) formed under hypoxia, which might be caused by many diseases. The concentration of ceruloplasmin in serum samples was determined by reaction with ortho-phenylenediamine [12].

The study of hepatoprotective activity of Artemisia absinthium and Artemisia vulgaris extracts was performed using the model of acute tetrachloromethane hepatitis [3]. Tablets Silibor as a hepatoprotector of local manufacturer (Preclinical Drug Research (Guidelines), 2001) was used as the reference drug.

The experiments were performed on white male rats without breed weighing 180-250 g. They were divided into 5 groups of 6 animals: animals of groups 1 and 2 were subcutaneously injected with Artemisia absinthium and Artemisia vulgaris extracts at a dose of $25 \mathrm{mg} / \mathrm{kg}$; animals of group 3 were treated with Silibor at a dose of $25 \mathrm{mg} / \mathrm{kg}$; animals of group 4 were not treated (control group); animals of group 5 were intact. The liver pathology was modeled by the single subcutaneous administration of $50 \%$ tetrachloromethane oil solution to the animals of the groups 1-4 at a dose of $0.8 \mathrm{ml}$ per $0.1 \mathrm{~kg}$ of animal weight for 2 days with an interval of 24 hours. The test substances and the reference drug were administered subcutaneously to the animals of groups 1 to 3, one hour before and two hours after administration of hepatotropic poison [14].

Animals were removed from the experiment by decapitation on the third day after the first injection of tetrachloromethane. Their blood was collected and the livers were removed. The conclusion about the efficacy of the tested extracts was made on the basis of biochemical parameters of the liver and serum determined 24 hours after the last injection of tetrachloromethane.

One of the criteria of the hepatoprotective effect of the test substances is the survival rate of animals [3].

The evaluation of the intensity of peroxide destructive transformations in the animals' body was determined by the content of TBA reactants in serum and liver homogenates. In serum there was also determined the activity of alanine aminotransferase (ALT), which is a hepatospecific marker of cytolysis.

The determination of ALT activity was carried out using the unified dinitrophenylhydrazine Reit-
man-Frankel method with the help of the standard set of SIMKO Ltd reagents [12].

The level of lipid peroxidation product (TBAreactants) was evaluated spectrophotometrically by reaction with 2-thiobarbituric acid. It was conducted by the method of E. N. Korobeinikova using biochemical sets of a local producer (set of reagents of Filisit-Diagnosis, Ukraine) [15].

Determination of arginase activity was performed according to the method of I. Snipacho in modification of V. A. Khramov and G. G. Lystopad [16].

For histological examination the liver was fixed in $10 \%$ neutral formalin solution, then dehydrated with alcohols of increasing concentration and put into the paraffin. Serial paraffin sections of 3-6 microns in thickness were made from paraffin blocks using the microtome MS-2 and were colored with hematoxylin and eosin. Tissue morphometry was performed using DP-SOFT morphometric software for Micros Austria microscope at $\times 100$ and $\times 200$ magnifications and using D 03 THIN camera.

RESULTS AND DISCUSSION. The maximum administered doses are conditionally accepted as $\mathrm{LD}_{50}$ for Artemisia absinthium and Artemisia vulgaris extracts. The results of toxicity studies of the extracts are shown in Table 1.

Received data indicate that intragastric administration of Artemisia absinthium and Artemisia vulgaris herb extracts at a dose of $6000 \mathrm{mg} / \mathrm{kg}$ does not lead to the death of animals (Table 1). Animals were tidy and had a good appetite. They responded adequately to sound and light stimulations. The urinary and defecation processes were normal, respiratory disorders and seizures were not observed.

The increase in body weight in the researched groups did not differ from the intact one (Table 2).

The research indicators of some hematological and biochemical parameters of experimental animals after 14 days of the experiment are shown in Table 3.

The results of the research indicate that peripheral blood parameters of mice after administration of Artemisia absinthium and Artemisia vulgaris extracts are within the intact group. It was found that there were no statistically significant changes in peripheral blood parameters after the single ad-

Table 1 - Results of the acute toxicity investigation of Artemisia L. herb extracts

\begin{tabular}{||l|c|c|c|}
\hline \multicolumn{1}{|c|}{$\begin{array}{c}\text { Name of the test } \\
\text { substance }\end{array}$} & $\begin{array}{c}\text { Dose, } \\
\mathrm{mg} / \mathrm{kg}\end{array}$ & $\begin{array}{c}\text { The result of monitoring, number of died animals/ } \\
\text { total number of animals in the group }\end{array}$ & Toxicity class \\
\hline $\begin{array}{l}\text { Artemisia absinthium herb } \\
\text { water-alcohol extract }\end{array}$ & 6000 & $0 / 6$ & V class \\
\hline $\begin{array}{l}\text { Artemisia vulgaris herb } \\
\text { water-alcohol extract }\end{array}$ & 6000 & $0 / 6$ & V class \\
\hline
\end{tabular}


Table 2 - Change in the body weight of experimental animals after a single administration of Artemisia absinthium and Artemisia vulgaris extracts

\begin{tabular}{|c|c|c|}
\hline \multirow[t]{2}{*}{ Test extracts } & \multicolumn{2}{|c|}{$\begin{array}{l}\text { The body weight of mice, } \mathrm{g} \text {, } \\
\qquad \overline{\mathrm{X}} \pm \Delta \overline{\mathrm{X}}, \mathrm{n}=6\end{array}$} \\
\hline & Before the experiment & After 14 days \\
\hline Artemisia absinthium herb water-alcohol extract & $19.50 \pm 0.77$ & $20.40 \pm 0.57$ \\
\hline Artemisia vulgaris herb water-alcohol extract & $19.60 \pm 0.55$ & $20.50 \pm 0.52$ \\
\hline Intact animals & $19.70 \pm 0.97$ & $20.80 \pm 0.63$ \\
\hline
\end{tabular}

Table 3 - Hematological and biochemical parameters of the mice blood after 14 days of administration of Artemisia absinthium and Artemisia vulgaris extracts

\begin{tabular}{|c|c|c|c|c|c|c|c|c|c|c|}
\hline \multirow[b]{2}{*}{ Test extracts } & \multicolumn{10}{|c|}{ Investigated parameters, , $\mathrm{n}=6$} \\
\hline & 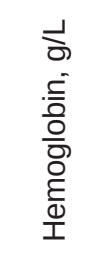 & 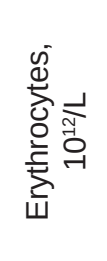 & 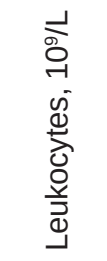 & 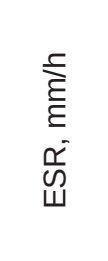 & 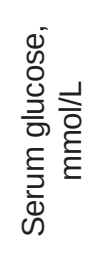 & 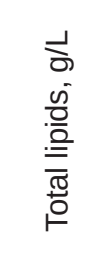 & 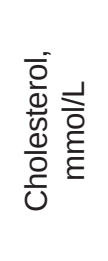 & 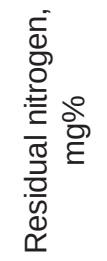 & 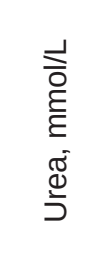 & 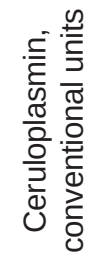 \\
\hline $\begin{array}{l}\text { Artemisia absinthium } \\
\text { herb water-alcohol } \\
\text { extract }\end{array}$ & $\begin{array}{l}130.80 \\
\pm 2.24^{\star}\end{array}$ & $\begin{array}{c}7.98 \\
\pm 0.35^{\star}\end{array}$ & $\begin{array}{c}7.60 \\
\pm 0.30^{*}\end{array}$ & $\begin{array}{c}4.18 \\
\pm 0.28^{*}\end{array}$ & $\begin{array}{c}6.15 \\
\pm 0.26^{*}\end{array}$ & $\begin{array}{c}6.35 \\
\pm 0.31^{*}\end{array}$ & $\begin{array}{c}2.89 \\
\pm 0.14^{*}\end{array}$ & $\begin{array}{c}39.20 \\
\pm 2.24^{*}\end{array}$ & $\begin{array}{c}42.50 \\
\pm 2.10^{\star}\end{array}$ & $\begin{array}{c}27.30 \\
\pm 1.98^{\star}\end{array}$ \\
\hline $\begin{array}{l}\text { Artemisia vulgaris } \\
\text { herb water-alcohol } \\
\text { extract }\end{array}$ & $\begin{array}{l}132.50 \\
\pm 2.21^{*}\end{array}$ & $\begin{array}{c}8.13 \\
\pm 0.27^{*}\end{array}$ & $\begin{array}{c}7.50 \\
\pm 0.26^{\star}\end{array}$ & $\begin{array}{c}4.06 \\
\pm 0.21^{*}\end{array}$ & $\begin{array}{c}6.20 \\
\pm 0.21^{*}\end{array}$ & $\begin{array}{c}6.46 \\
\pm 0.28^{\star}\end{array}$ & $\begin{array}{c}2.88 \\
\pm 0.11^{*}\end{array}$ & $\begin{array}{c}38.90 \\
\pm 2.01^{*}\end{array}$ & $\begin{array}{c}43.30 \\
\pm 2.28^{\star}\end{array}$ & $\begin{array}{c}27.70 \\
\pm 2.25^{\star}\end{array}$ \\
\hline Intact animals & $\begin{array}{c}132.80 \\
\pm 2.80\end{array}$ & $\begin{array}{c}8.11 \\
\pm 0.43 \\
\end{array}$ & $\begin{array}{r}7.40 \\
\pm 0.28 \\
\end{array}$ & $\begin{array}{c}4.08 \\
\pm 0.21\end{array}$ & $\begin{array}{c}6.23 \\
\pm 0.27 \\
\end{array}$ & $\begin{array}{c}6.41 \\
\pm 0.30\end{array}$ & $\begin{array}{c}2.82 \\
\pm 0.18\end{array}$ & $\begin{array}{l}38.50 \\
\pm 2.28\end{array}$ & $\begin{array}{r}43.80 \\
\pm 2.43 \\
\end{array}$ & $\begin{array}{l}26.20 \\
\pm 1.20 \\
\end{array}$ \\
\hline
\end{tabular}

Note * - the reliability of deviation of these groups in relation to intact animals $(p \leq 0.05)$.

ministration of herbal extracts in the acute experiment.

The study of hematological and biochemical parameters of mice blood after single administration of Artemisia absinthium and Artemisia vulgaris extracts shows the absence of toxic effect on the body. It is confirmed by the activity of antioxidant protection, which is within the limits, and hematological parameters - the number of leukocytes, erythrocytes and hemoglobin level in the peripheral blood are within the indicators of the intact animals.

Ceruloplasmin is a major extracellular antioxidant. It also acts as a transporter of copper ions and it is a donor of copper for the synthesis of enzymes that are responsible for tissue respiration and energy metabolism, hemoglobin synthesis, hematopoietic processes. It is an important factor in preventing the development of endotoxicosis and immune natural protection of the body. The liver is one of the most important barriers to endotoxicosis. It provides detoxification processes in the body by preventing the development of multiple organ dysfunction and insufficiency. Reduction of ceruloplasmin activity in pathological diseases is regarded as the formation of liver dysfunction and the significant decrease in activity - as the development of liver failure and is an indicator of the formation of poly organ failure. Therefore, determination of the activity of ceruloplasmin in the blood is one of the important indicators of the functional state of the liver.

Livers of intact and experimental animals in macroscopic examination are visually unchanged and occupy the typical locations. At the optical level of liver histological sections examination of the control animals was found that the liver lobes had clear contours. Hepatocytes form liver beams that radially diverge from the central vein. There is an uneven blood supply of sinusoidal capillaries in the perisinusoidal spaces. The connective tissue layers are visualized in the perivascular space (Fig. 1).

Hepatocytes of the liver of experimental animals have the typical structures, arranged in two rows

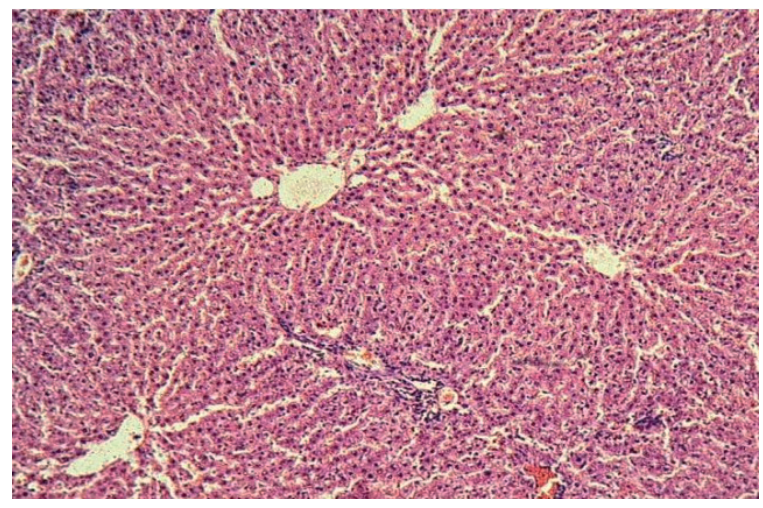

Fig. 1. Histostructure of the liver of the control animal. Coloring: hematoxylin and eosin. Magnification: $\times 100$. 
and formed in the liver lobe beams (Fig. 2). These are cells of polygonal shape, preferably with one round nucleus, that are centrally located, containing one or two nuclei.

The central vein is radially approached by sinusoids. The lumen of the sinusoidal hemocapillaries is irregular in shape and contains single erythrocytes. In the perisinusoidal space, the thin reticular fibers of the connective tissue are traced. Microscopic examination revealed that the liver structure of animals of the control and experimental groups corresponds to normal. The results of biochemical studies of blood serum and liver homogenate in acute toxic liver damage are shown in Table 4.

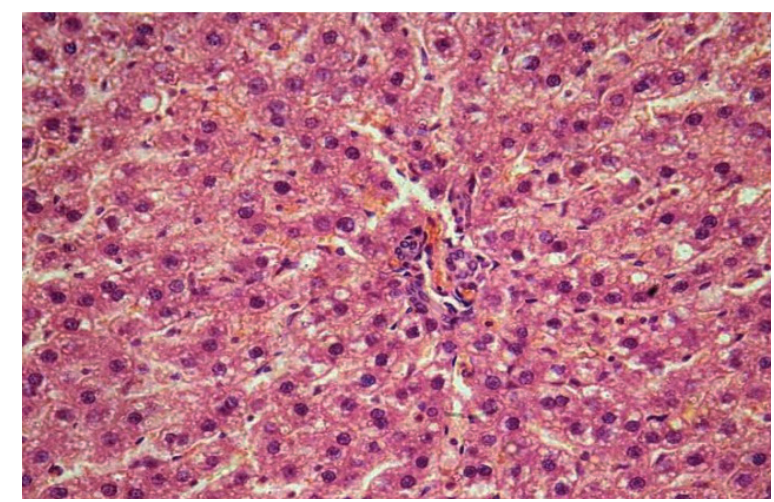

Fig. 2. Histostructure of the liver of the experimental animal - water-alcohol extract of Artemisia absinthium. Coloring: hematoxylin and eosin. Magnification: $\times 100$.

Table 4 - The influence of Artemisia absinthium and Artemisia vulgaris extracts on biochemical parameters of blood serum and liver condition in acute hepatitis

\begin{tabular}{|c|c|c|c|c|c|}
\hline \multirow[b]{2}{*}{$\begin{array}{c}\text { Biochemical } \\
\text { and hematological } \\
\text { parameters }\end{array}$} & \multicolumn{3}{|c|}{ Test extracts } & \multirow{2}{*}{$\begin{array}{l}50 \% \text { oil } \\
\text { solution of } \\
\text { tetrachloro- } \\
\text { methane }\end{array}$} & \multirow[b]{2}{*}{ Intact animals } \\
\hline & $\begin{array}{c}\text { Artemisia } \\
\text { absinthium herb } \\
\text { water-alcohol } \\
\text { extract }\end{array}$ & $\begin{array}{c}\text { Artemisia vulgaris } \\
\text { herb water-alcohol } \\
\text { extract }\end{array}$ & $\begin{array}{l}\text { Tablets } \\
\text { "Silibor" }\end{array}$ & & \\
\hline Dose, mg/0.1 kg & 2.5 & 2.5 & 2.5 & $0.8 \mathrm{ml}$ & - \\
\hline \multicolumn{6}{|c|}{ Blood serum } \\
\hline $\mathrm{ALT}, \mu \mathrm{kmol} / \mathrm{h} \mathrm{mL}$ & $0.56 \pm 0.03^{*}$ & $0.69 \pm 0.04^{*}$ & $0.27 \pm 0.01^{\star \star}$ & $1.36 \pm 0.04^{\star \star}$ & $0.24 \pm 0.02$ \\
\hline TBA reactants, $\mathrm{nmol} / \mathrm{mL}$ & $3.80 \pm 0.21^{\star}$ & $4.02 \pm 0.16^{\star \star}$ & $3.86 \pm 0.05^{\star}$ & $5.84 \pm 0.02^{\star *}$ & $3.52 \pm 0.07$ \\
\hline Arginase, $\mu \mathrm{kmol} / 0.1 \mathrm{mg}$ & $0.306 \pm 0.060$ & $0.310 \pm 0.008$ & $0.302 \pm 0.007$ & $0.410 \pm 0.011$ & $0.290 \pm 0.007$ \\
\hline $\begin{array}{l}\text { Ceruloplasmin, } \\
\text { conventional units }\end{array}$ & $25.20 \pm 1.20$ & $24.80 \pm 1.18$ & $25.90 \pm 1.21$ & $19.80 \pm 1.16$ & $26.20 \pm 1.20$ \\
\hline \multicolumn{6}{|c|}{ Liver homogenate } \\
\hline TBK reactants, $\mu \mathrm{kmol} / \mathrm{g}$ & $32.40 \pm 1.17^{*}$ & $37.10 \pm 1.17^{* \star}$ & $33.50 \pm 0.87^{* *}$ & $62.20 \pm 1.51^{\star \star}$ & $26.20 \pm 0.63$ \\
\hline
\end{tabular}

Note. * - the reliability of the deviation relative to the data of the intact animals group $(p \leq 0.05) ;{ }^{\star *}-$ the reliability of the deviation relative to the data of the control animals group $(p \leq 0.05)$.

The received data (Table 4) indicate that the single administration of tetrachloromethane was accompanied by the development of acute toxic liver damage. Significant intensification of lipid peroxidation processes and depletion of the antioxidant protection system were observed in experimental animals, resulting in impaired structural and functional integrity of membranes. The destruction of the components of the cell membrane caused the development of the distinct cytolytic syndrome, as evidenced by the increase of ALT activity to $(1.36 \pm 0.04)$ at normal $(0.24 \pm 0.015) \mu \mathrm{kmol} / \mathrm{h} \mathrm{mL}$ and arginase enzyme activity (which is a highly specific indicator of the function of the hepatocyte membranes and its organelles) to $(0.410 \pm 0.011)$ at normal $(0.230 \pm 0,007) \mu \mathrm{kmol} / 0.1 \mathrm{~mL}$. Simultaneously, the activity of ceruloplasmin, which is a leading extracellular blood antioxidant synthesized in hepatocytes due to the combination of alpha-2 globulin fraction with 6 copper atoms, changes in the opposite direction - $(19.8 \pm 1)$ conventional units at normal $(26.2 \pm 1.20)$ conventional units.
Using the Artemisia absinthium and Artemisia vulgaris extracts and the Silibor tablets in experimental hepatitis was accompanied by a remarkable improvement of the studied parameters. Thus, the ALT activity after administration of the test extracts decreased by $58.8 \%$ and $49.3 \%$ respectively, and the activity of enzyme indicators changed in the direction of normalization and equaled $(0.306 \pm 0.006)$ and $(0.310 \pm 0.008) \mu \mathrm{kmol} / 0.1 \mathrm{~mL}$ respectively, whereas the activity of ceruloplasmin corresponded to the level of intact animals.

Silibor tablets show the better effect on the development of cytolysis syndrome causing the normalization of ALT activity, ceruloplasmin and arginase activity, which equaled $(0.302 \pm 0.007) \mathrm{kmol} / 0.1 \mathrm{ml}$.

The synchronous use of hepatotropic poison and Artemisia absinthium and Artemisia vulgaris extracts resulted in the decrease of the levels of TBA reactants in the blood serum by $35.0 \%$ and $31.2 \%$ respectively and in the liver homogenate by $47.9 \%$ and $40.3 \%$ respectively. The use of Silibor tablets leads to decrease in the level of TBA reac- 
tants in the blood serum and liver homogenates by $34.2 \%$ and $46.1 \%$ respectively.

The received data show that extracts of Artemisia absinthium and Artemisia vulgaris herb in the case of acute toxic liver damage show the distinct hepatoprotective activity. They suppress peroxide destructive processes and reduce the progress of cytolysis syndrome and their effects are no inferior rather than the effect of Silibor tablets.

CONCLUSIONS. 1. It was found that intragastric administration of Artemisia absinthium and Artemisia vulgaris herb extracts at a dose of $6000 \mathrm{mg} / \mathrm{kg}$ does not lead to the death of animals, does not occur changes in the integral, hematological, biochemical parameters and morphological structure of the internal organs of experimental animals. It indicates the absence of the toxicity of extracts at this dose and characterizes them as almost non-toxic ones ( $V$ toxicity class, $\mathrm{LD}_{50}>5000 \mathrm{mg} / \mathrm{kg}$ ) according to the toxicity classification of substances.

\section{LITERATURE}

1. Фитотерапия семейного врача / В. Ф. Корсун, Е. В. Корсун, Н. А. Огренич, Б. А. Султанбеков. - М., 2014. -469 c.

2. Бобкова І. А. Фармакогнозія / І. А. Бобкова, В. В. Бур'янова. - К. : Медицина, 2017. - 326 с.

3. Доклінічні дослідження лікарських засобів : метод. рек. / за ред. О. В. Стефранова. - К. : Авіцена, 2001. -528 c.

4. Тимчишин О. Л. Вплив медгерму на функціональний стан печінки при гострому токсичному гепатиті / О. Л. Тимчишин, В. Й. Кресюн, В.В.Годован // Інтегративна антропологія. - 2011. - № 2 (18). C. $66-73$.

5. Ассаср М. М. Експериментальне вивчення впливу густих екстрактів лопуха великого на перебіг модельного гепатиту у щурів / М. М. Ассафр, К. Г. Щокіна, С. М. Дроговоз // Укр. біофармац. журн. - 2012. № 4 (21). - C. 44-48.

6. A review of the pharmacological effects of Arctium lappa (burdock) / Y. S. Chan, L. N. Cheng, J. H. Wu [et al.] // Inflammopharmacology. - 2011. - No. 19 (5). P. 245-254.

7. Hepatoprotective effects of Arctium lappa Linne on liver injuries induced by chronic ethanol consumption and potentiated by carbon tetrachloride / S. C. Lin, C. H. Lin, C. C. Lin [et al.] // J. Biomed. Sci. - 2002. 9. - No. 5. - P. 401-409.

8. Койро О. О. Експериментальне обґрунтування застосування екстракту яглиці звичайної при сполучному токсичному ураженні печінки та нирок / О. О. Кой-
2. The obtained data show that the Artemisia absinthium and Artemisia vulgaris herb extracts exhibit hepatoprotective activity in acute toxic liver damage. It leads to the decrease in the intensity of the lipid peroxidation process and the decrease in the toxic effect of tetrachloromethane; the biochemical parameters of the animals' blood and liver homogenate are normalized to the level of intact animals.

3. The received results indicate that water-alcohol extract of Artemisia absinthium herb at a dose of $25 \mathrm{mg} / \mathrm{kg}$ of the animal body weight showed more intense effect in acute hepatitis in comparison with the water-alcohol extract of Artemisia vulgaris herb.

Further pharmacological experimental study of Artemisia absinthium and Artemisia vulgaris extracts as the medicinal plant raw materials with bactericidal, choleretic, anti-inflammatory and cytotoxic effects is promising.

Conflict of interest: we wish to confirm that there are no known conflicts of interest associated with this publication. ро, О. В. Товчига, С. Ю. Штриголь // Укр. біофрармац. журнал. - 2011. - № 2 (13). - С. 24-28.

9. Державна Фармакопея України : в 3 т. / Державне підприємство "Український науковий фрармакопейний центр якості лікарських засобів". - 2-ге вид. X. : Державне підприємство "Український науковий фармакопейний центр якості лікарських засобів", 2015. - 1. - 1128 c.

10. Добреля Н. В. Розвиток європейського законодавства в сорері використання тварин у наукових експериментах / Н. В. Добреля, Є. В. Стрєлков, Т. А. Бухтіарова // Фармакологія та лікар. токсикологія. - 2014. - № 2. - С. 88-91.

11. Commission of the European Communities: Council Directive of 18 December 1986 on the Lows, regulating the Application of Principles of Good Laboratory Practice and the Verification of Their Applications for Tests on Chemical Substances (87/18/EEC) / The Rules Governing Medicinal Products in the European Community. - 1991. - 1. - P. 145-146.

12. Лабораторные методы исследования в клинике : справочник / [В. В. Меньшиков, Л. Н. Делекторская, Р. П. Золотницкая и др.] ; под ред. В. В. Меньшикова. - М.: Медицина, 1987. - 368 с.

13. Струк О. А. Дотримання етичних норм при проведенні фрармакологічних досліджень/О.А.Струк ; гол. ред. В. В. Вашкевич // Гілея: науковий вісник : зб. наук. пр. - К. : Гілея, 2017. - Вип. 117 (2). - С. 177-180.

14. Позняков В. С. Изменение фрункционального состояния у крыс при воздействии четыреххлористо- 
го углерода / В. С. Позняков, Н. Г. Иванов // Токсикология новых промышленных химических веществ. М. : Медицина, 1979. - Вып. 15. - С. 87-89.

15. Коробейникова Е. Н. Модисрікація визначення продуктів перекисного окислювання ліпідів у реакції 3 тіобарбітуровою кислотою / Е.Н.Коробейникова // Лаб. дело. - 1989. - № 7. - С. 8-10.

\section{REFERENCES}

1. Korsun, V.F., Korsun, E.V., Ogrenich, N.A., \& Sultanbekov, B.A. (2014). Fitoterapiya semeynogo vracha [Herbal medicine of family doctor]. Moscow [in Russian].

2. Bobkova, I.A., \& Burianova, V.V. (2017). Farmakohnoziia [Pharmacognosy]. Kyiv: Medytsyna [in Ukrainian].

3. Stefanov, O.V. (2001). Doklinichni doslidzhennia likarskykh zasobiv (metodychni rekomendatsii) [Preclinical studiesof drugs (Guidelines)]. Kyiv: Avitsena [in Ukrainian].

4. Tymchyshyn, O.L., Kresiun, V.Y., \& Hodovan, V.V. (2011). Vplyv medhermu na funktsionalnyi stan pechinky pry hostromu toksychnomu hepatyti [Influence of medgerma on the functional state of the liver in acute toxic hepatitis]. Intehratyvna Antropolohiia - Integrative Anthropology, 2 (18), 66-73 [in Ukrainian].

5. Assaf, M.M., Shchokina, K.H., \& Drohovoz, S.M. (2012). Eksperymentalne vyvchennia vplyvu hustykh ekstraktiv lopukha velykoho na perebih modelnoho hepatytu u shchuriv [Experimental study of the effect of thick burdock extracts on the course of model hepatitis in rats]. Ukrainskyi biofarmatsevtychnyi zhurnal - Ukrainian Biopharmaceutical Journal, 4 (21), 44-48 [in Ukrainian].

6. Chan, Y.S., Cheng, L.N., Wu, J.H., Chan, E. Kwan Y.W., Lee, S.M., ... Chan, S.W. (2011). A review of the pharmacological effects of Arctium lappa (burdock). Inflammopharmacology, 19 (5), 245-254.

7. Lin, S.C., Lin, C.H., Lin, C.C., Lin, Y.H., Chen, C.F., Chen, I.C. \& Wang, L.Y. (2002). Hepatoprotective effects of Arctium lappa Linne on liver injuries induced by chronic ethanol consumption and potentiated by carbon tetrachloride. J. Biomed. Sci., 9 (5), 401-409.

8. Koiro, O.O., Tovchyha, O.V., \& Shtryhol, S.Yu. (2011). Eksperymentalne obhruntuvannia zastosuvannia ekstraktu yahlytsi zvychainoi pry spoluchnomu toksychnomu urazhenni pechinky ta nyrok [Experimental justification for the use of common juniper extract in the connective liver and kidney toxicity]. Ukrainskyi biofarmatsevtychnyi zhurnal - Ukrainian Biopharmaceutical Journal, 2 (13), 24-28 [in Ukrainian].

9. Derzhavna Farmakopeia Ukrainy (2015): v 3 t. Derzhavne pidpryiemstvo "Ukrainskyi naukovyi farmakopeinyi tsentr yakosti likarskykh zasobiv" [State Pharmacopoeia of Ukraine: in 3 volumes SE "Ukrainian Scientific Pharmacopoeial Centre of Drugs Quality"]. $2^{\text {nd }}$ edition.
16. Храмов В. А. Модисикация метода определения орнитина по Chinard и ее использование для количественного определения сывороточной аргиназы / В. А. Храмов, Г. Г. Листопад // Лаб. дело. 1973. - № 10. - С. 591-592.

Kharkiv: State enterprise "Ukrainian Scientific Pharmacopoeial Centre of Drugs Quality" [in Ukrainian].

10. Dobrelia, N.V., Strielkov, Ye.V., \& Bukhtiarova, T.A. (2014). Rozvytok yevropeiskoho zakonodavstva v sferi vykorystannia tvaryn u naukovykh eksperymentakh [Development of European legislation in the field of using animals in scientific research]. Farmakolohiia ta likarska toksykolohiia - Pharmacology and Drug Toxicology, 2, 88-91 [in Ukrainian].

11. Commission of the European Communities (1991). Council Directive of 18 December 1986 on the Lows, regulating the Application of Principles of Good Laboratory Practice and the Verification of their Applications for Tests on Chemical Substances (87/18/EEC). The Rules Governing Medicinal Products in the European Community.

12. Menshikov, V.V., Delektorskaya, L.N., \& Zolotnitskaya, R.P. (1987). Laboratornye metody issledovaniya $v$ klinike. Spravochnik [The methods of the laboratory research in the clinic. Reference book]. Moscow: Meditsina [in Russian].

13. Struk, O.A. (2017). Dotrymannia etychnykh norm pry provedenni farmakolohichnykh doslidzhen [Compliance with ethical standards in the pharmacological research]. Vashkevych, V.V. (Ed.). Hileia: naukovyi visnyk. Zbirnyk naukovykh prats. Hileia: a scientific bulletin. Collection of scientific works. Kyiv: Hileia [in Ukrainian].

14. Poznyakov, V.S., \& Ivanov, N.G. (1979). Izmenenie funktsionalnogo sostoyaniya u krys pri vozdeystvii chetyrekhkhloristogo ugleroda [Changes in functional status in rats when exposed to carbon tetrachloride]. Toksikologiya novykh promyshlennykh khim. Veshhestv Toxicology of new industrial chem. Substances. Moscow: Meditsina [in Russian].

15. Korobeynikova, E.N. (1989). Modyfikatsiia vyznachennia produktiv perekysnoho okysliuvannia lipidiv u reaktsii z tiobarbiturovoiu kyslotoiu [Modification for determination of the products of lipid peroxidation in reaction with thiobarbituric acid]. Laboratornoe delo Laboratory Work, 7, 8-10 [in Ukrainian].

16. Khramov, V.A., \& Listopad, G. (1973). Modifikatsiya metoda opredeleniya ornitina po Chinard i ee ispolzovanie dlya kolichestvennogo opredeleniya syvorotochnoy arginazy [Modification of the Chinard method for determining ornithine and its use for the quantification of serum arginase]. Laboratornoe delo - Laboratory Science, 591-592. 
Р. А. Грицик ${ }^{1}$, О. А. Струк², В. М. Іваночко 2 НАЦІОНАЛЬНИЙ ФАРМАЦЕВТИЧНИЙ УНІВЕРСИТЕТ ${ }^{1}$, ХАРКІВ IВАНО-ФРАНКІВСЬКИЙ НАЦІОНАЛЬНИЙ МЕДИЧНИЙ УНІВЕРСИТЕТ

\section{ДОСЛІДЖЕННЯ ВПЛИВУ ЕКСТРАКТІВ 3 ТРАВИ ВИДІВ РОДУ ПОЛИН НА ПЕРЕБІГ ТОКСИЧНОГО ТЕТРАХЛОРМЕТАНОВОГО УРАЖЕННЯ ПЕЧІНКИ}

Вступ. Одним з перспективних джерел створення лікарських препаратів із гепатопротекторною активністю є види роду Полин, які застосовують як апетитні, глистогінні, бактерицидні, жовчогінні та протизапальні засоби, дія яких зумовлена наявністю різних груп біологічно активних сполук.

Мета дослідження - вивчити гостру токсичність та вплив водно-спиртових екстрактів з трави полину гіркого і полину звичайного на перебіг токсичного тетрахлорметанового ураження печінки.

Методи дослідження. Для визначення гострої токсичності використовували методику доклінічного вивчення безпечності лікарських засобів. Гепатозахисну активність екстрактів з трави полину гіркого та полину звичайного вивчали на моделі гострого тетрахлорметанового гепатиту. Як препарат порівняння застосовували гепатопротектор вітчизняного виробництва - таблетки "Силібор".

Результати й обговорення. У результаті проведеного дослідження встановлено, що внутрішньошлункове введення екстрактів з трави полину гіркого та полину звичайного в дозі 6000 мг/кг не призводило до загибелі тварин, змін зі сторони інтегральних, гематологічних, біохімічних показників та морфрологічної структури внутрішніх органів піддослідних тварин не виникало, що вказувало на відсутність токсичної дії екстрактів у цій дозі та характеризувало їх як практично нетоксичні (V клас токсичності, $L D_{50}>5000$ мг/кг) відповідно до класифрікації речовин за токсичністю. Результати вивчення гепатопротекторної активності екстрактів з трави полину гіркого та полину звичайного свідчили про те, що при гострому токсичному ураженні печінки вони проявляли виражену гепатопротекторну активність, пригнічуючи пероксидні деструктивні процеси та зменшуючи розвиток синдрому цитолізу, і практично не поступалися за гепатопротекторною активністю препарату порівняння "Силібор".

Висновки. Гостра токсичність після внутрішньошлункового введення екстрактів з трави полину гіркого та полину звичайного в дозі 6000 мг/кг не призводила до загибелі тварин, вони були охайними, мали задовільний апетит, нормально реагували на звукові й світлові подразники, процеси сечовиділення і дефрекації були в нормі, порушень дихання та судом не спостерігали. Досліджувані екстракти з трави полину гіркого та полину звичайного проявляють при гострому токсичному ураженні печінки гепатопротекторну активність, про що свідчать зниження інтенсивності процесу пероксидного окиснення ліпідів і зменшення токсичності діі тетрахлорметану, доводячи біохімічні показники крові тварин та гомогенату печінки до рівня інтактних тварин.

КЛЮЧОВІ СЛОВА: гостре токсичне ураження тетрахлорметаном; екстракти; полин гіркий; полин звичайний; гістологічне дослідження.

\section{ИССЛЕДОВАНИЕ ВЛИЯНИЯ ЭКСТРАКТОВ С ТРАВЫ ВИДОВ РОДА ПОЛЫНЬ НА ТЕЧЕНИЕ ТОКСИЧЕСКОГО ТЕТРАХЛОРМЕТАНОВОГО ПОРАЖЕНИЯ ПЕЧЕНИ}

\section{Резюме}

Вступление. Одним из перспективных источников создания лекарственных препаратов с гепатопротекторной активностью являются виды рода Полынь, которые применяют как аппетитные, глистогонные, бактерицидные, желчегонные и противовоспалительные средства, действие которых обусловлено наличием различных групп биологически активных соединений.

Цель исследования - изучить острую токсичность и влияние водно-спиртовых экстрактов с травы полыни горькой и полыни обыкновенной на течение токсического тетрахлорметанового поражения печени.

Методы исследования. Для определения острой токсичности использовали методику доклинического изучения безопасности лекарственных средств. Гепатозащитную активность экстрактов с травы 
полыни горькой и полыни обыкновенной изучали на модели острого тетрахлорметанового гепатита. $B$ качестве препарата сравнения применяли гепатопротектор отечественного производства - таблетки "Силибор".

Результаты и обсуждение. В результате проведенного исследования установлено, что внутрижелудочное введение экстрактов с травы полыни горькой и полыни обыкновенной в дозе 6000 мг/кг не приводило к гибели животных, изменений со стороны интегральных, гематологических, биохимических показателей и морфологической структуры внутренних органов подопытных животных не возникало, что указывало на отсутствие токсического действия экстрактов в этой дозе и характеризовало их как практически нетоксичные (V класс токсичности, $L D_{50}>5000$ мг/кг) в соответствии с классификацией веществ по токсичности. Результаты изучения гепатопротекторной активности экстрактов с травы полыни горькой и полыни обыкновенной свидетельствовали о том, что при остром токсическом поражении печени они проявляли выраженную гепатопротекторную активность, подавляя перекисные деструктивные процессы, уменьшая развитие синдрома цитолиза, и практически не уступали по гепатопротекторной активности препарату сравнения "Силибор".

Выводы. Острая токсичность после внутрижелудочного введения экстрактов с травы полыни горькой и полыни обыкновенной в дозе 6000 мг/ке не приводила к гибели животных, они были опрятными, имели удовлетворительный аппетит, нормально реагировали на звуковые и световые раздражители, процессы мочеиспускания и дефекации были в норме, нарушений дыхания и судорог не наблюдали. Исследуемые экстракты с травы полыни горькой и полыни обыкновенной проявляют при остром токсическом поражении печени гепатопротекторную активность, о чем свидетельствуют снижение интенсивности процесса перекисного окисления липидов и уменьшение токсичности тетрахлорметана, доводя биохимические показатели крови животных и гомогената печени до уровня интактных животных.

КЛЮЧЕВЫЕ СЛОВА: острое токсическое поражение тетрахлорметаном; экстракты; полынь горькая; полынь обыкновенная; гистологическое исследование.

Received 30.10.19

Address for correspondence: O. A. Struk, Ivano-Frankivsk National Medical University, Galyska str. 2, Ivano-Frankivsk, 76018, Ukraine, e-mail: sanichka5@gmail.com. 